\title{
INCUBATION AND REARING-EFFORT PARTITIONING OF WING-BANDED HORNERO Furnarius figulus (PASSERIFORMES: FURNARIIDAE)
}

\author{
LAGOS, A. R., ${ }^{1}$ MARQUES, R. V., ${ }^{2}$ MORENO, A. B., ${ }^{3}$ SILVA, K. V. K. A. ${ }^{3}$ and ALVES, M. A. S. ${ }^{4}$ \\ ${ }^{1}$ Programa de Pós-graduação em Ecologia, Universidade Federal do Rio de Janeiro \\ ${ }^{2}$ Programa de Pós-Graduação em Biologia, Universidade do Estado do Rio de Janeiro \\ ${ }^{3}$ Programa de Iniciação Científica, Universidade do Estado do Rio de Janeiro \\ ${ }^{4}$ Departamento de Ecologia, Instituto Biologia, Universidade do Estado do Rio de Janeiro, \\ Rua São Francisco Xavier, 524, CEP 20550-011, Rio de Janeiro, RJ, Brazil \\ Correspondence to: Maria Alice S. Alves, Departamento de Ecologia, Instituto de Biologia, Universidade do Estado do \\ Rio de Janeiro, Rua São Francisco Xavier, 524, CEP 20550-011, Rio de Janeiro, RJ, Brazil, e-mail: masa@uerj.br \\ Received May 19, 2003 - Accepted October 24, 2003 - Distributed May 31, 2005
}

(With 1 figure)

\begin{abstract}
We studied incubation and feeding rates in two of five broods in two oven nests of Furnarius figulus at Lagoa Rodrigo de Freitas. During incubation, the number of visits and time spent in the nest did not differ between the adults. The number of feeding visits was significantly different between members of the breeding pair of the first but not of the second nest. Nestlings received arthropods, fishes, and larvae in the first nest and, in the second, arthropods, larvae, and fruits. The nestlings stayed about 23 days in the nests.
\end{abstract}

Key words: Furnarius figulus, oven nest, incubation, rearing, Lagoa Rodrigo de Freitas.

\section{RESUMO}

\section{Incubação e distribuição de esforços para criação de Furnarius figulus} (Passeriformes: Furnariidae)

Estudamos a incubação e a alimentação de ninhegos de duas ninhadas em dois ninhos de forno ocupados por Furnarius figulus na Lagoa Rodrigo de Freitas. Durante a incubação, o número de visitas e o tempo gasto no ninho não diferiram entre os adultos. No primeiro ninho houve diferença significativa entre os membros do par reprodutor quanto ao número de visitas alimentares aos ninhegos, mas no segundo, essa diferença não ocorreu. No primeiro ninho, os ninhegos receberam artrópodes, peixes e larvas e no segundo, artrópodes, larvas e frutas. A permanência dos ninhegos nos dois ninhos foi de cerca de 23 dias.

Palavras-chave: Furnarius figulus, ninho de forno, incubação, Lagoa Rodrigo de Freitas.

Furnariidae is one of the major exclusively neotropical bird families (Sick, 1997). Species of this family build diverse types of closed nests (Collias, 1997). Horneros of the genus Furnarius usually build or occupy so-called clay oven nests. The Wing-banded Hornero Furnarius figulus is endemic in Brazil, occurring from Pará to Rio de Janeiro (Sick, 1997). Previous records mention this species in oven nests (Snethlage, 1935), in epiphytic bromeliads and under a roof (Studer \& Vielliard,
1990), and between the bases of large leaves of a palm tree (Sick, 1997). However, there are not enough studies of the breeding biology of $F$. figulus to confirm if this species actually builds or just occupies oven nests. In this study, we recorded five broods in two oven nests occupied by F. figulus at an urban lagoon in Rio de Janeiro. In these two nests, we measured incubation and feeding rates in nestlings by members of a breeding pair during two broods in different years. 
The study was carried out alongside of Lagoa Rodrigo de Freitas in Rio de Janeiro, RJ, Brazil. This coastal lagoon and its immediate surroundings are used for public recreation. Beyond these areas, buildings abound and the streets are heavily trafficked (Alves \& Pereira, 1998).

The first nest was found in December 2000 (22 58'35.0"S; 4312'94.4”W), and the second, some $20 \mathrm{~m}$ from the first, in May 2001. Broods were occupying the first nest in February 2001 and in late 2001; in the second nest this was happening in June and September of 2002 and in April 2003. However, only the February 2001 and June 2002 broods were followed during incubation and rearing. Breeding was recorded only at the second nest.

By using a hand net, adult birds were trapped within the nest. In February 2001, one bird was weighted (34 g) during incubation and fitted with metal bands (IBAMA-CEMAVE) and colored plastic bands. A second adult bird weighing 36.5 $\mathrm{g}$ was also banded in June 2002 at the second nest during incubation. After both members of the breeding pair were marked, we recorded the same individuals breeding as a pair in June 2002, September 2002, and April 2003.

The nestlings were captured in the nest, weighted, and marked: one in the first nest (33 g) and one in the second (35 g). Equipped with binoculars $(7 \times 35)$, we alternated watching (ARL: 22 h; RVM: 20 h; ABM: 18 h; KVKAS: 8 h; and MASA: $28 \mathrm{~h}$ ) at a location some $10 \mathrm{~m}$ from the nests. Observation time during the day for each nest was $48 \mathrm{~h}$, with $30 \mathrm{~h}$ for incubation and 18 $\mathrm{h}$ for rearing at nest 1 , and $24 \mathrm{~h}$ for incubation and $24 \mathrm{~h}$ for rearing at nest 2 . For the first nest, incubation observations extended from January 31 to February 2, and February 13-14; rearing observations were also divided into initial and final periods (February 21-23 and March 2-3, respectively). The incubation observations for the second nest were also divided into initial and final periods of two days each (May 30-31; June 6-7); the same happened with the rearing observations (June 13-14 and June 25-26). We observed the nests for $6 \mathrm{~h}$ per day, with $2 \mathrm{~h}$ intervals between the three daily observation periods (on the first day, from 6-8 h, followed by a 2-hour interval, and so on; on the second day, observation began between 8-10 h and followed the same pattern).

In the first nest there were possibly two nestlings (at least two eggs were touched by MASA, and more than one nestling called during rearing), but only one was found alive 10 days after the nestlings hatched. The second nest had two nestlings, but only one was individually marked while the other was found dead at the nest entrance. During incubation, the time spent in the nest and the number of visits by members of the breeding pair were recorded. During rearing, the number of visits and the food items brought to the nestlings were also recorded. Time spent in the nest during rearing was quantified only for the second nest.

To compare the feeding rates and the time spent in the nest by both members of the breeding pair, the number of visits and time spent in the nest per $2 \mathrm{~h}$ (the interval of observation time) were used. Differences in these rates were tested using the Kruskal-Wallis test, since data were not normally distributed (Zar, 1999).

In the first nest, members of the pair shared incubation during the day, and did not significantly differ in number of visits, whose average number was 1.5 visits/h for the unmarked individual and 2.5 visits/h for the marked one $(\mathrm{N}=30 \mathrm{~h})$. The marked bird watched during $22.2 \%$ of the time, and the unmarked one, $27.8 \%$. Time spent in the nest during incubation also did not differ between members of the breeding pair. The minimum and maximum times spent in the nest by a visiting bird were 0.1 and $44 \mathrm{~min}$, respectively. Considering the different observation periods ( $2 \mathrm{~h}$ each), the total number of visits per hour varied from 7.5 (16-18 h) to $10.5(12-14 \mathrm{~h})$. The nest was unattended for $50.1 \%$ of the time $(\mathrm{N}=30 \mathrm{~h})$. Time away from the nest varied from 1 to $117 \mathrm{~min}$ (average $\pm \mathrm{sd}=15+$ $17 \mathrm{~min}$ ), and $30 \mathrm{sec}$ to $120 \mathrm{~min}(22 \pm 25 \mathrm{~min})$, for the first and second marked individuals, respectively. The incubation period, although not precisely recorded, was between 19 and 24 days, as nestlings hatched between February15 and 19. Nestlings stayed in the nest for between 21 and 25 days.

At the second nest, both members of the breeding pair shared incubation, and did not significantly differ in number of visits. The average number of visits/h for the newly marked individual was 1.1 ; it was 1.5 for the already marked one $(\mathrm{N}=$ $24 \mathrm{~h}$ ). The individual already marked was present $29.1 \%$ of the time, while the other individual was for $20.4 \%$. The time spent in the nest also did not differ between members of the pair. The minimum and maximum times spent in the second nest by each bird were $0.1 \mathrm{~min}$ and $59 \mathrm{~min}$, respectively. 
Considering the different observation periods $(2 \mathrm{~h}$ each), the total number of visits per hour varied from 3.5 (16-18 h) to 7 (6-8 h), with an intermediate value around midday. The nest was unattended for $32.8 \%$ of the time $(\mathrm{N}=24 \mathrm{~h})$. Time away from nest varied from $10 \mathrm{sec}$. to $98 \mathrm{~min}$. (average $\pm \mathrm{sd}=18 \pm 12$ $\mathrm{min})$, and 1 to $120 \mathrm{~min}(12 \pm 15 \mathrm{~min})$, for the first and second marked individuals, respectively. The nestlings hatched between June11 and 13, and remained for between 22 and 24 days.

Members of the pair shared parental care and incubating. Since the first bird was marked during incubation, and the observations were made from a distance of about $10 \mathrm{~m}$, the bird marked might have been nervous, which could have caused reduced incubation (50\% time away from the nest, an unusually low amount of time for incubating birds). At the second nest, the bird marked in the first nest incubated more, and total incubation was much more than it was in the first nest. Banding the unmarked bird at the second nest could have caused it to incubate less, resulting in the greater percentage recorded for the first marked bird, although another possible factor is the heavy human traffic in the vicinity of the lagoon.

At the first nest, feeding visits $(\mathrm{N}=162)$ to nestlings differed significantly between marked and unmarked individuals (Mann-Whitney, $\mathrm{U}^{\prime}=81$, $\mathrm{p}<0.001, \mathrm{~N}=9$, df = 1), being higher for the marked individual $(77.8 \%)$. The average number of visits/h was 7.0 for the marked bird and 2.0 for the unmarked. Food items brought to the nestlings ( $\mathrm{N}=161)$ included arthropods, fishes, larvae, and unidentified items, with arthropods making up about $50 \%$ (Table 1). The arthropods $(\mathrm{N}=81)$ were mainly insects $(54.3 \%)$, crustaceans $(37.0 \%)$, spiders (1.2\%), and unidentified items (7.4\%). The insects which could be identified $(\mathrm{N}=23)$ were: Coleoptera (47.8\%), Hymenoptera (39.1\%), Orthoptera (4.3\%), and Diptera $(8.7 \%)$.

TABLE 1

Food items brought to the nestlings by a breeding pair of Furnarius figulus in two nests at Lagoa Rodrigo de Freitas. In brackets are values per hour.

\begin{tabular}{|c|c|c|c|c|c|c|}
\hline \multirow{2}{*}{$\begin{array}{c}\text { Nests } \\
\text { First }\end{array}$} & \multicolumn{6}{|c|}{ Food itens } \\
\hline & Bird & Arthropods & Fishes & Larvae & Unidentified & Total \\
\hline \multirow{3}{*}{$\begin{array}{c}\text { Initial } \\
(6 \mathrm{~h})\end{array}$} & Marked & $9(1.5)$ & $9(1.5)$ & 0 & $30(5)$ & $48(8)$ \\
\hline & Unmarked & $5(0.8)$ & $4(0.7)$ & 0 & $4(0.7)$ & $13(2.2)$ \\
\hline & Sub-total & $14(2.3)$ & $13(2.2)$ & 0 & $34(5.7)$ & $61(10.2)$ \\
\hline \multirow{3}{*}{$\begin{array}{l}\text { Final } \\
(12 \text { h })\end{array}$} & Marked & $51(4.3)$ & $14(1.2)$ & $11(0.9)$ & 0 & $76(6.3)$ \\
\hline & Unmarked & $16(1.3)$ & $1(0.1)$ & $2(0.2)$ & $6(0.5)$ & $24(2)$ \\
\hline & Sub-total & $67(5.6)$ & $15(1.3)$ & $13(1)$ & $6(0.5)$ & $100(8.3)$ \\
\hline Total & & 81 & 28 & 13 & 39 & 161 \\
\hline$\%$ & & 50.3 & 17.4 & 8.1 & 24.2 & \\
\hline Second & Bird & Arthropods & Larvae & Fruit & Unidentified & Total \\
\hline \multirow{3}{*}{$\begin{array}{l}\text { Initial } \\
(12 \mathrm{~h})\end{array}$} & Marked & $21(1.7)$ & $4(0.3)$ & $3(0.2)$ & $3(0.2)$ & $31(2.6)$ \\
\hline & Unmarked & $29(2.4)$ & $2(0.2)$ & $1(0.1)$ & $8(0.7)$ & $40(3.4)$ \\
\hline & Sub-total & $50(4.2)$ & $6(0.5)$ & $4(0.3)$ & $11(0.9)$ & $71(5.9)$ \\
\hline \multirow{3}{*}{$\begin{array}{l}\text { Final } \\
(12 \text { h) }\end{array}$} & Marked & $26(2.7)$ & $5(0.4)$ & 0 & $11(0.9)$ & $42(3.5)$ \\
\hline & Unmarked & $46(3.8)$ & $5(0.4)$ & 0 & $5(0.4)$ & $56(4.7)$ \\
\hline & Sub-total & $72(6)$ & $10(0.8)$ & 0 & $16(1.3)$ & $98(8.2)$ \\
\hline Total & & 122 & 16 & 4 & 27 & 169 \\
\hline$\%$ & & 72.2 & 9.5 & 2.4 & 15.9 & \\
\hline
\end{tabular}


At the second nest, feeding visits $(\mathrm{N}=183)$ to nestlings did not differ significantly between individuals. The average number of visits/h was 4.0 for the recently marked individual and 3.6 for the previously marked one. Food items brought to nestlings ( $\mathrm{N}=169$ ) included arthropods, larvae, fruit, and unidentified items (Table 1). The arthropods ( $\mathrm{N}=$ $122)$ were insects $(79.5 \%)$, crustaceans $(1.8 \%)$, and unidentified items $(18.8 \%)$. The insects identified $(\mathrm{N}=56)$ were: Hymenoptera $(26.8 \%)$, Blattaria (26.8\%), Diptera (25\%), Coleoptera (12.4\%), Hemiptera (3.6\%), Orthoptera (3.6\%), and Lepidoptera (1.8\%).

Thus, feeding visits varied among members of the pair. The first marked individual made $77.8 \%$ of the total visits at the first nest, but at the second nest, the second marked individual made $52.8 \%$ of the visits.

Nestling and incubation periods were like those registered by Studer \& Vielliard (1990), who observed nestlings leaving after 22 days, and reported a 20-day incubation period. The first marked individual was apparently a male, judging by its behaviour in defending the nest (always calling and displaying intensively when other birds or a human was trying to reach the nest). The higher feeding-visit frequency for the marked individual at the first nest indicates that differences in parental care occur between sexes of $F$. figulus. However, at the second nest there were no significant feedingvisit differences. The major asymmetry in relation to feeding visits at the first nest could be due to the higher availability of food at the edge of Lagoa Rodrigo de Freitas because of fish mortality during that time.

The main food items brought to nestlings were arthropods, especially insects. However, food items varied between the two broods, being mainly fishes at the first nest and larvae at the second nest. The relatively high frequency of fishes and crustaceans at the first nest can be explained because of their greater availability, resulting from high mortality registered between 21 and 23 February 2001. This seems to indicate that $F$. figulus is an opportunistic species relative to food resources.

The time spent in the second nest during rearing differed significantly between members of the breeding pair in the initial period (Mann-Whitney,
$\left.\mathrm{U}^{\prime}=34, \mathrm{p}=0.01, \mathrm{~N}=6, \mathrm{df}=1\right)$, being about twice that for the first marked individual $(37.7 \pm 17.3 \mathrm{~min})$. But it did not differ in the final period $(7.2 \pm 11.3$ and $3.0 \pm 2.9 \mathrm{~min}$ for the first and second marked individuals, respectively). The time spent in the nest in the initial and final periods differed significantly for the first and second marked individuals (Mann-Whitney, $\mathrm{U}^{\prime}=28, \mathrm{p}=0.02, \mathrm{~N}=$ $6, \mathrm{df}=1$ and $\mathrm{U}^{\prime}=29, \mathrm{p}=0.01, \mathrm{~N}=6, \mathrm{df}=1$, respectively). This indicates that these birds brooded their nestlings more when the young were small.

Approximately 23 days after the nestlings left the second nest, one member of the breeding pair was seen feeding the fledgling on the ground.

Feeding visits were not recorded for a third unmarked individual often found next to the second nest during incubation and rearing periods. Once this bird, which could have been a nestling from a previous brood, entered the nest and removed feces.

The first oven nest was on a branch of an introduced almond tree, Terminalia catappa, at 7 $\mathrm{m}$ above ground and $4 \mathrm{~m}$ from the edge of the lagoon. Early in the morning, the nest received little direct sunlight. It measured $22.0 \mathrm{~cm}$ wide by 31.0 $\mathrm{cm}$ long, $20.0 \mathrm{~cm}$ in height, with the entrance 12.5 $\mathrm{cm}$ high and $5.0 \mathrm{~cm}$ wide. The second oven nest was also found on a branch of another Terminalia catappa (Fig. 1) bordering the lagoon, at $10 \mathrm{~m}$ above ground and $12 \mathrm{~m}$ from the lagoon border. The second nest also received little direct sunlight, and measured $20.0 \mathrm{~cm}$ in height, was $23.0 \mathrm{~cm}$ wide and $14.0 \mathrm{~cm}$ long, with an entrance $9.0 \mathrm{~cm}$ high and $7.0 \mathrm{~cm}$ wide.

The nest type of F. figulus is a matter of discussion. Snethlage (1935) described the nest of this species in Pará State as a classical oven. But Studer \& Vielliard (1990) suggested that the oven nest described by Snethlage (1935) could have been built by $F$. minor or F. leucopus. To support this hypothesis, Studer \& Vielliard (1990) mentioned nests of this species in Alagoas State being found in bromeliads and also under a roof. So far, nidification of $F$. figulus has not yet been researched sufficiently (Sick, 1997). The fact that F. figulus occurs in certain areas in which no oven nests have been recorded implies, according to Sick (1997), that this species does not build nests of this type. 


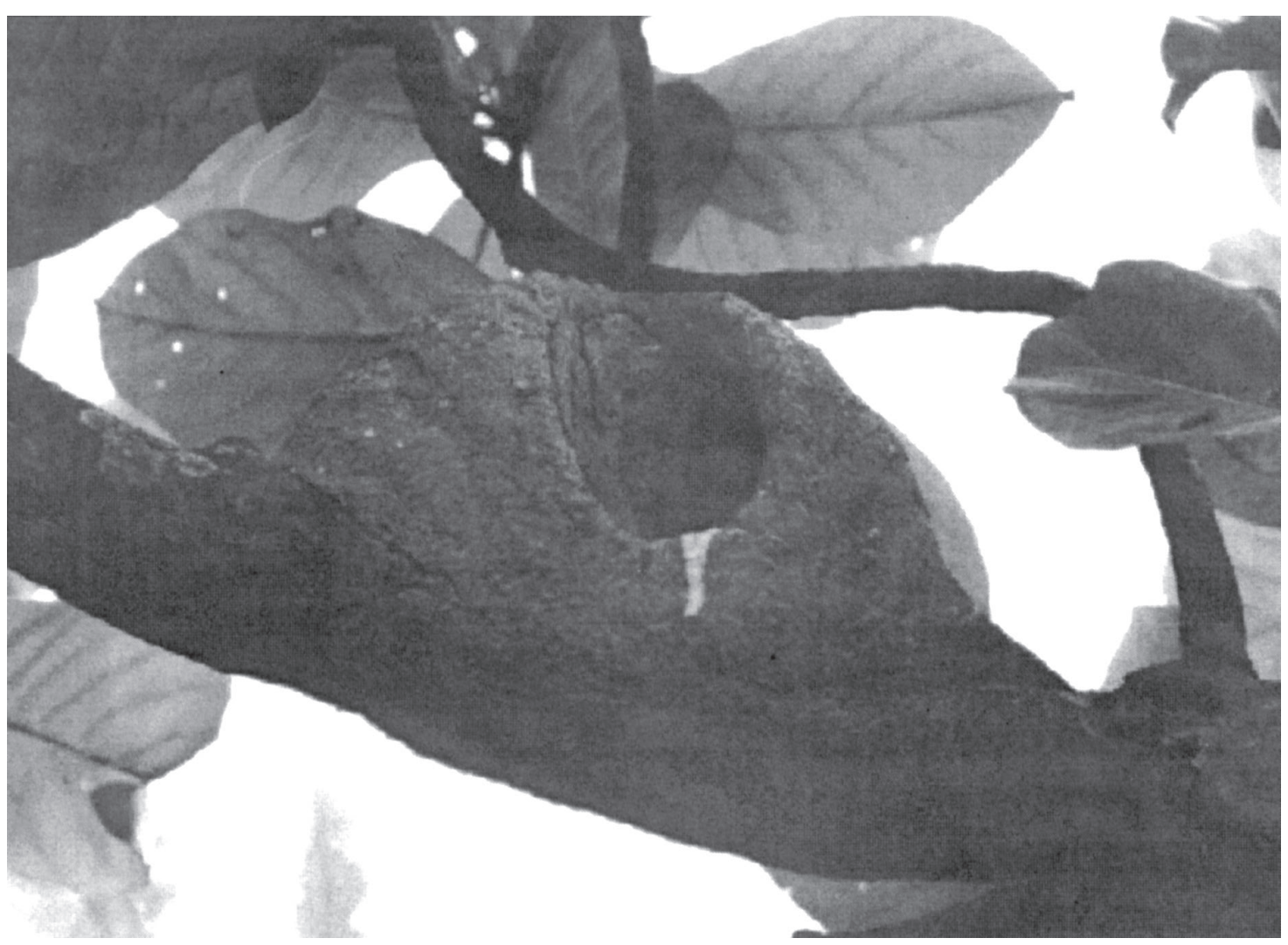

Fig. 1 - Oven-nest occupied by Furnarius figulus at Lagoa Rodrigo de Freitas, RJ. Photo by M. A. S. Alves.

In the present study, we did not observe $F$. figulus building the nests, but only occupying and carrying lining material to them. A third oven nest occupied by F. figulus was also found on which, however, no observations were made. We recorded Furnarius rufus building and breeding in oven-nests in the study area close to both nests occupied by F. figulus. Therefore, F. figulus might possibly occupy nests built by $F$. rufus. In addition, ARL observed an individual of $F$. figulus carrying food to a nest located between the bases of the crown of a coconut palm, in March 2003, in Guarapari, Espírito Santo State. Besides that, in October 2003 in Lagoa Rodrigo de Freitas we observed F. figulus building an open nest in a palm tree. These last discoveries reinforce the hypothesis that $F$. figulus does not build oven nests, although we do not have enough evidence to reject the alternative hypothesis. Final resolution of this question requires additional observations.

Acknowledgements - This study is part of the results of the Ecology, Conservation, and Management of the Southeastern Brazilian Ecossystem Program and of the Southeastern Brazilian Vertebrate Ecology Project (Departamento de Ecologia, Instituto de Biologia, Universidade do Estado do Rio de Janeiro). We thank E. O. Willis for his critical review of previous versions, which improved the manuscript; Davor Vrcibradic for his review; the Universidade do Estado do Rio de Janeiro (UERJ) for transportation support; and the members of the Avian Ecology Group (UERJ). This study was partially supported by a research grant from Conselho Nacional do Desenvolvimento Científico e Tecnológico (CNPq) (process n. 302718/2003-6) to M. A. S. Alves, and also by graduate fellowships from CNPq to A. R. Lagos and FAPERJ to R. V. Marques. A. B. Moreno, and K. A. V. K. Silva received a Initial Scientific Grant from PIBIC UERJ/CNPq and FAPERJ, respectively. 


\section{REFERENCES}

ALVES, M. A. S. \& PEREIRA, E. F., 1998, Richness, abundance and seasonality of bird species in a lagoon of an urban area (Lagoa Rodrigo de Freitas) of Rio de Janeiro. Ararajuba, 6(2):110-116

COLLIAS, N. E., 1997, On the origin and evolution of nest building by passerine birds. The Condor, 99: 253-270.

SICK, H., 1997, Ornitologia brasileira, uma introdução. Editora Nova Fronteira, Rio de Janeiro, 823p.
SNETHLAGE, E., 1935, Beiträge zur Brutbiologie brasilianischer Vögel. J. Orn., 83: 1-24; 532-564.

STUDER, A. \& VIELLIARD, J., 1990, The nest of the Wingbanded Hornero Furnarius figulus in Northeastern Brazil. Ararajuba, 1: 39-41.

ZAR, J. H., 1999, Biostatistical analysis. $4^{\text {th }}$ ed. Prentice Hall Inc., Upper Saddle River, 663p. 